\title{
LOS REGLAMENTOS EN ESPAÑA: LA FUENTE DEL DERECHO MÁS COMÚN Y QUIZÁ LA MÁS DESCONOCIDA
}

\section{Decrees: the most common and perhaps the most unknown source of rights in Spain}

\author{
Lorenzo Cotino Hueso'
}

\section{Resumen}

En esta investigación se analizan los efectos que, en España, producen los reglamentos, que son normas emanadas de la administración. Estos, en innumerables casos los prevalecen por encima de la ley y de los tratados internacionales, y que, además en la práctica, terminan por regular importantes espacios sociales y del Estado, ocasionando una enorme inseguridad jurídica.

\section{Palabras clave}

Reglamentos en España, inseguridad jurídica, reglamentos administrativos.

1 Profesor titular del Departamento de Derecho constitucional y Ciencia política y de la Administración de la Universitat de Valencia, coordinador de la Red de Especialistas en Derecho de las Tecnologías de la Información y Comunicación, www.derechotics.com. Licenciado y doctor en Derecho y licenciado y DEA en Ciencia política. Dirección electrónica: cotino@uv.es, www.cotino.net (donde se puede acceder a muchas de sus publicaciones).

El presente estudio se ha realizado en el marco del proyecto de investigación "De la administración al gobierno electrónicos: régimen e implicaciones jurídicas y constitucionales" (SEJ2005-09191/JURI), MEC, 2006-2008. 


\section{Abstract}

The text analyses the legal effects that decrees, an administrative norm, cause in Spain. Decrees do not only prevail in uncountable cases over laws and international treaties, they also regulate important social and public spaces. Consequently, they lead to an enormous legal insecurity.

\section{Key words}

Decrees in Spain, legal insecurity, administrative decrees.

\section{A MODO DE INTRODUCCIÓN}

Si acudimos a una base de datos legislativa al uso sería sencillo percibir que del 95 al $99 \%$ de las normas que arrojaría como resultado una búsqueda total no son aquellas que suelen ser el objeto de enseñanza y estudio en las facultades: ni tratados internacionales, ni leyes, ni normas con fuerza de ley. Bajo una terminología y forma muy diversa y emanados de una pluralidad de entidades muy amplia, a esta inmensa cantidad de normas se les puede denominar "reglamentos", pese a que no se autodenominen como tales. Como señala Santamaría Pastor:
Se trata, en efecto, de un ámbito literalmente inmenso: un gigantesco almacén en el que se deposita no menos del $\mathbf{9 8}$ por $\mathbf{1 0 0}$ de las disposiciones que integran el sistema normativo, en el que las normas presentan una variedad extraordinaria, poco menos que aberrante y en que, sobre todo, los principios clásicos del Estado de Derecho poseen una eficacia ciertamente disminuida. Un ámbito fuertemente peculiar, escasamente conocido y frene al que los operadores jurídicos parecen sufrir una cierta alergia (Santamaría, 2000, pp. 305-362).

De hecho, la misma Constitución española que dedica diez artículos a las normas con rango de

2 Las referencias, ciertamente indirectas, son las que siguen (la cursiva es propia):

Artículo 62. Corresponde al Rey:

f) Expedir los decretos acordados en el Consejo de Ministros, conferir los empleos civiles y militares y conceder honores y distinciones con arreglo a las leyes.

Artículo 97: El Gobierno dirige la política interior y exterior, la Administración civil y militar y la defensa del Estado. Ejerce la función ejecutiva y la potestad reglamentaria de acuerdo con la Constitución y las leyes.

Artículo 105: La ley regulará:

a) La audiencia de los ciudadanos, directamente o a través de las organizaciones y asociaciones reconocidas por la ley, en el procedimiento de elaboración de las disposiciones administrativas que les afecten.

Artículo 106: 1. Los tribunales controlan la potestad reglamentariay la legalidad de la actuación administrativa, así como el sometimiento de ésta a los fines que la justifican.

Artículo 153: El control de la actividad de los órganos de las Comunidades Autónomas se ejercerá: [...] c) Por la jurisdicción contencioso-administrativa el de la administración autónoma y sus normas reglamentarias.

Artículo 161: [...] 2. El Gobierno podrá impugnar ante el Tribunal Constitucional las disposiciones y resoluciones adoptadas por los órganos de las comunidades autónomas. La impugnación producirá la suspensión de la disposición o resolución recurrida, pero el tribunal, en su caso, deberá ratificarla o levantarla en un plazo no superior a cinco meses. 
ley (arts. 81-91 CE), cuenta con seis alusiones fugaces, punto menos que vergonzantes -recuerda este autor-, a los reglamentos (artículos 62. f), 97, 105 a) 106. $\left.1^{\circ}, 153 . C\right)$ y 161.2 (E) $)^{2} . Y$ es que, afirma Santamaría, el mundo de los reglamentos es el dominio reservado y doméstico de la Administración, en el que la dinámica del poder público se muestra en toda su crudeza, despojado de las reglas de cortesía y urbanidad a las que se ve obligado a atenerse cuando actúa en el escalón normativo de las leyes y la Constitución ${ }^{3}$.

Pues bien, a lo largo de las siguientes páginas se pretende dar una visión española lo más clara posible de este oscuro mundo de los reglamentos; si se me permite, la hermana fea de las fuentes del Derecho; categoría que, como tal, aún hoy suscita no pocas dudas en la doctrina y jurisprudencia. Y ello contrasta con que el reglamento acabe siendo no sólo la fuente del Derecho cuantitativamente más importante, sino la más manejada por los operadores jurídicos, cuanto menos del Derecho público.

\section{QUÉ ES UN REGLAMENTO}

\section{1 Una definición de reglamento}

Dado que no es totalmente pacífico qué puede regular un reglamento, quién puede aprobarlo, qué nombre recibe $y$ otras cuestiones, frente a definiciones más amplias como la de Parejo ${ }^{4}$ lo mejor -creo- es optar una definición laxa: reglamento es una norma escrita de rango inferior a la ley que emana de un Gobierno y/o Administración. Se trata de una definición sencilla que no difiere de la que en las últimas ediciones ofrecen García de Enterría y Ramón-Fernández (2002, pp. 179-235) , o como las de Parada (2004, pp. 58-72 $)^{6}$, Santamaría (p. 307) ${ }^{7}$, de Otto $(1987$, pp.214-242) o Garrido Falla (2002, pp. 270-294)

3 Ibíd.

4 Así, por ejemplo, la completa definición ofrecida por Parejo Alfonso, quien señala que un reglamento es una norma:

$1^{\circ}$ que emana del Gobierno (Nación-Comunidades Autónomas) actuando en cualquiera de sus formaciones posibles, colegiadas (originaria) o individuales, por delegación singular o desconcentración.

$2^{\circ}$ En ejercicio de la potestad propia reglamentaria, subordinada a la ley.

$3^{\circ}$ De rango y eficacia inferiores a la ley.

$4^{\circ}$ Que se ordena con las demás de su misma clase en función de la jerarquía y según la posición en la estructura organizativa de quien la dicta (art. 23.3 Ley del Gobierno).

Añade que la norma estatutaria, aunque constitutiva de una variedad específica es equiparable al reglamento en tanto producto de la potestad reglamentaria y se relaciona con éste según el principio de competencia y emana del correspondiente órgano superior directivo de la entidad territorial o sectorial, dotada de autonomía. También por extensión reciben tratamiento de reglamento las normas dictadas en ejercicio de una potestad reglamentaria derivada de las Administraciones independientes (Parejo, pp. 255-299).

5 Creo que puede decirse sin temor a equivocarse o ser subjetivo, que se trata de la obra de referencia en España en Derecho administrativo, sin perjuicio de la existencia de numerosos juristas de Derecho público, especialmente administrativo, consagrados. Se trata de

En una de las primeras ediciones definía el reglamento como "Acto normativo dictado por la Administración en ejercicio de su competencia propia, con destinatarios indeterminados, con efectos generales, que innova e integra el ordenamiento jurídico con subordinación a la ley". En la edición citada de 2002, simplemente señalan que "Se llama reglamento a toda norma escrita dictada por la Administración" (pág. 179).

6 Este significativo y crítico administrativista, opta por una sencilla definición: "toda norma escrita con rango inferior a la ley dictada por una Administración".

7 Santamaría define los reglamentos como "normas dictadas por el complejo gobierno-administración y caracterizadas por ser su rango o fuerza inferior a la de ley".

8 Sin ser administrativista, la monografía sobre fuentes de este autor ha destacado sobremanera entre la doctrina. La definición de este autor (p. 214), señala que los reglamentos son: "normas jurídicas dictadas por la Administración o, más en general, por órganos del Estados o del poder público que no ostentan la potestad legislativa".

9 Quien fuese significativo magistrado del Tribunal Constitucional, define el reglamento como "toda disposición jurídica de carácter general dictada por la Administración pública y con valor subordinado a la ley". 
Esta norma de fuerza inferior a la ley es dictada por quien tiene potestad reglamentaria, esto es, un poder en virtud del cual se pueden dictar reglamentos.

\subsection{El porqué de los reglamentos}

La existencia de reglamentos, con su muy variada forma, procedencia y contenidos se explica por diversos motivos. Hoy día, es el desarrollo del Estado social el fenómeno que lleva a que se apruebe una innumerable la cantidad de reglamentos, el incremento de normas reglamentarias ha sido parejo al de importancia y presencia del Estado en las sociedades modernas. La acción estatal y administrativa es tan ingente y afecta a tantos ámbitos que resultaría totalmente inoperante y disfuncional que tuviera que ser el legislador soberano quien llevase a cabo su regulación completa. Como apuntan García de Enterría y Tomás-Ramón, frente a la solemnidad y lentitud de la ley, el Estado social requiere de continuidad, dinamismo y conocimientos técnicos. A decir de Garrido Falla, son diversas las razones que justifican la existencia de los reglamentos (p.271):

- La composición política y no técnica del parlamento hace que éste no sea el idóneo para aprobar normas del contenido propio (generalmente detallado y técnico) de los reglamentos. La Administración cuenta con mejores y mayores medios técnicos y humanos para ello.

- La movilidad y dinamismo de las normas administrativas exigen que no se otorgue a muchas materias el rango formal de ley, para facilitar su derogación y sustitución por otras normas.

- Con los reglamentos la Administración se autolimita frente a la amplia discrecionalidad que es propia al ejecutivo en su actuación.

- El legislador parlamentario no puede -ni debe- prever todos los casos que puedan surgir en la aplicación y desarrollo de las leyes que aprueba.

\subsection{Distinción de figuras afines}

Hay que ubicar a los reglamentos entre las figuras con las que puede ser en su caso confundido y guarda alguna afinidad: la ley, el acto administrativo y las circulares, instrucciones y órdenes.

\subsubsection{Ley y reglamento}

Como señalan García de Enterría y RamónFernández, lo único común entre ley y reglamento es que son normas escritas generales (2002, p. 281), todo lo demás varía esencialmente. La ley en España se define esencialmente por provenir del Parlamento (nacional o autonómico), quien tradicionalmente expresa la voluntad general de la comunidad. Frente a ello el reglamento procede del Gobierno y/o la Administración y de natural es técnico, concreto y limitado y respecto de la ley (a la que por lo general desarrolla y ejecuta) es subordinado, subalterno, inferior $y$ complementario. En España, mientras que la ley regula lo que quiera sometida únicamente a la Constitución, el reglamento requiere de justificación caso por caso, y está limitado por la ley. Asimismo, a diferencia de la ley el reglamento es controlable -e inaplicable- por un juez, incluso y como se verá- a requerimiento de sus destinatarios.

\subsubsection{Reglamento y acto administrativo}

La distinción acto administrativo-reglamento no siempre es clara. En la actualidad la distinción se articula entre "disposiciones generales" -o "disposiciones de carácter general" $\mathrm{y}$ "disposiciones particulares" o "actos administrativos" (Art. 51 y 
Ss. Ley $30 / 1992^{10}$, así como art. 25 y ss de la Ley $29 / 1998^{11}$ ). Pese a esta terminología general-particular, este criterio es insuficiente: hay reglamentos singulares (por ejemplo: la configuración de una unidad ministerial) y se ha abierto la generalidad de los actos administrativos (Ilamamiento a filas, fijación de fiestas locales, órdenes de policía, licitaciones, etc.). Por ello, sólo en principio, los reglamentos tienen un destinatario general, en el sentido de abstracción objetiva, mientras que los actos administrativos son destinatarios concretos y singulares.

Como no siempre es sencillo diferenciar estas figuras, pueden seguirse algunas guías marcadas, entre otros, por Santamaría:

- Los reglamentos tienen un procedimiento de elaboración diferente del de los actos, como luego se hace referencia (como el artículo 24 de la Ley del Gobierno ${ }^{12}$ o 49 de la Ley de Bases del Régimen Local).

- La publicación es esencial para que los reglamentos adquieran eficacia (Art. 24. 4 Ley Gobierno, Art. 70 LBRL), mientras que sólo excepcionalmente para los actos administrativos (Art. 60 Ley 30/1992), para los que por lo general se requiere notificación (Art. 57. $2^{\circ}$ Ley 30/1992).

- Los reglamentos son derogables libremente, si bien la figura respecto de los actos administrativos es la revocación, sometida a límites materiales (Art. 105 Ley 30/1992).

- Aunque sólo en principio, los reglamentos tienen un destinatario general, en el senti- do de abstracción objetiva, mientras que los actos administrativos son destinatarios concretos y singulares. No obstante, hay reglamentos singulares (por ejemplo: la configuración de una unidad ministerial) y se ha abierto la generalidad de los actos administrativos (llamamiento a filas, fijación de fiestas locales, órdenes de policía, licitaciones, etc.).

- Recuerda en este caso Montilla otra diferencia, la inderogabilidad singular de los reglamentos. En otras palabras, un acto administrativo singular, proceda de donde proceda, no puede derogar un reglamento (Art. 52. 2 Ley 30/1992 y art. 23. 4 Ley del Gobierno).

En todo caso, y sin perjuicio de lo anterior, la diferencia conceptual más aceptada es la subrayada por García de Enterría y Ramón-Fernández (2002, p. 281): "Ios reglamentos ordenan y los actos son ordenados", es decir, los primeros innovan el ordenamiento jurídico mientras que los actos administrativos son aplicación del éste. El acto administrativo, sea singular o general su círculo de destinatarios, se consume con su cumplimiento, para un nuevo cumplimiento habrá que dictar eventualmente un nuevo acto. En cambio, la norma no se consume con su cumplimiento singular, antes bien se mantiene y se refuerza por los sucesivos cumplimientos. Aceptando como fundamental este criterio distintivo, cabe apostillar que, como recuerda de Otto, hay actos administrativos que permanecen en el tiempo, como la declaración de día festivo (De Otto, $1987)^{13}$.

10 Ley 30/1992, de 26 de noviembre, de Régimen Jurídico de las Administraciones Públicas y del Procedimiento Administrativo Común, una ley esencial en España. En concreto, se hace referencia al Título V, “De las disposiciones y los actos administrativos", Capítulo II, “Disposiciones administrativas".

11 Ley 29/1998, reguladora de la jurisdicción contencioso-administrativa (LJCA), en concreto, Título III, Objeto del recurso C Contencioso-Administrativo, Capítulo I, "Actividad administrativa impugnable".

12 Ley 50 /1997, de 27 de noviembre, del Gobierno, luego se sigue dicho precepto.

13 Para De Otto el criterio es innovar el ordenamiento, norma que perdura en el tiempo, pero advierte que hay actos administrativos generales que permanecen en el tiempo, como declaración de día festivo. 
Hay que decir también, que lejos de ser una mera disquisición intelectual esta diferenciación actoreglamento puede tener efectos prácticos y procesales bien importantes:

- El sistema de control y recursos de uno u otro varía mucho: no cabe impugnación administrativa directa de los reglamentos, sólo jurisdiccional, a través de los recursos directo, indirecto y las cuestiones de legalidad. Asimismo, en general es posible el recurso de casación respecto de los reglamentos y sólo excepcionalmente respecto de los actos administrativos. En este sentido, hay zonas grises y en ocasiones, se han suscitado dudas respecto de la "Relación de puestos de trabajo" (artículo 17 de la Ley 30/1984) en el ámbito de la función pública o los diversos instrumentos de planeamiento en urbanismo ${ }^{14}$. Unos y otros sí han sido considerados por los tribunales disposiciones de ca- rácter general a los efectos de fiscalización jurisdiccional ${ }^{15}$.

- $\quad$ Si son contrarios al ordenamiento jurídico, los reglamentos pueden ser inaplicados por los jueces y la sanción es siempre la nulidad de pleno derecho y la invalidez. A diferencia de aquéllos, los actos administrativos contrarios al ordenamiento jurídico son anulables en general. Sólo en casos concretos la sanción de los actos administrativos es la sanción más grave de la nulidad de pleno Derecho (Art. 62 y 63 de la Ley $30 / 1992^{16}$ ).

\subsubsection{Circulares, instrucciones y órdenes de servicio}

La cuestión se hace si se quiere más vidriosa cuando se trata de las Circulares, Instrucciones y Órdenes de Servicio. Como se regula en el artículo $21.1^{\circ}$ de la Ley $30 / 1992^{17}$, "Ios órganos administrativos podrán dirigir las actividades de sus

14 En la Comunidad Valenciana, por ejemplo, Planes Generales (PGOU), Planes Parciales, Planes de Reforma Interior, Catálogos de Bienes y Espacios Protegidos, Programas para el desarrollo de Actuaciones Integradas (PAI), Estudios de Detalle.

15 Aunque no los proyectos de reparcelación o de urbanización, por ejemplo.

16 Artículo 62. Nulidad de pleno derecho.(Modificado por Ley 4/1999): "1. Los actos de las Administraciones Públicas son nulos de pleno derecho en los casos siguientes:

a) Los que lesionen los derechos y libertades susceptibles de amparo constitucional.

b) Los dictados por órgano manifiestamente incompetente por razón de la materia o del territorio.

c) Los que tengan un contenido imposible.

d) Los que sean constitutivos de infracción penal o se dicten como consecuencia de ésta.

e) Los dictados prescindiendo total y absolutamente de procedimiento legalmente establecido o de las normas que contienen las reglas esenciales para la formación de la voluntad de los órganos colegiados.

f) Los actos expresos o presuntos contrarios al ordenamiento jurídico por los que se adquieren facultades o derechos cuando se carezca de los requisitos esenciales para su adquisición.

g) Cualquier otro que se establezca expresamente en una disposición de rango legal.

2. También serán nulas de pleno derecho las disposiciones administrativas que vulneren la Constitución, las leyes u otras disposiciones administrativas de rango superior, las que regulen materias reservadas a la Ley, y las que establezcan la retroactividad de disposiciones sancionadoras no favorables o restrictivas de derechos individuales."

Artículo 63. Anulabilidad: "1. Son anulables los actos de la Administración que incurran en cualquier infracción del ordenamiento jurídico, incluso la desviación de poder.

2. No obstante, el defecto de forma sólo determinará la anulabilidad cuando el acto carezca de los requisitos formales indispensables para alcanzar su fin o dé lugar a la indefensión de los interesados.

3. La realización de actuaciones administrativas fuera del tiempo establecido para ellas sólo implicará la anulabilidad del acto cuando así lo imponga la naturaleza del término o plazo."

17 Artículo 21. Instrucciones y órdenes de servicio: "1. Los órganos administrativos podrán dirigir las actividades de sus órganos jerárquicamente dependientes mediante instrucciones y órdenes de servicio

Cuando una disposición específica así lo establezca o se estime conveniente por razón de los destinatarios o de los efectos que puedan producirse, las instrucciones y órdenes de servicio se publicarán en el periódico oficial que corresponda." 
órganos jerárquicamente dependientes mediante instrucciones y órdenes de servicio". A veces bajo el calificativo de "resolución" o "circular" son emitidas desde distintos cargos en la jerarquía administrativa (Secretarios de Estado, Subsecretarios, Directores generales, etc.). En algunas leyes autonómicas son reguladas con mayor deta$\mathrm{Il}^{18}$. Las instrucciones y órdenes se utilizan de forma tan habitual como descuidada $y$ asistemática, generándose problemas en tanto a su eficacia y valor jurídico $(1987)^{19}$, o sus garantías, por cuanto no siguen el procedimiento de los reglamentos así como porque en principio no son publicadas. Cabe señalar que si bien pueden ser publicadas como prescribe el art. 21. $1^{\circ}$ Ley $30 / 1992$, ello, en principio no parece dotarles de carácter reglamentario ${ }^{20}$.

\section{Estas instrucciones y órdenes no son reglamen- tos por no ser emitidas por órgano con potestad}

18 En algunas normas autonómicas recientes las órdenes e instrucciones se han recibido con algún mayor detalle. Así por ejemplo, puede mencionarse la Ley 1/2002, de 28 febrero de la Asamblea de Extremadura que regula el Gobierno y Administración de la Comunidad Autónoma de Extremadura, en concreto su artículo 71: “De las instrucciones, circulares y órdenes de servicio:

“1. Los órganos superiores y directivos impulsarán y dirigirán la actividad administrativa mediante la emanación de instrucciones, circulares y órdenes de servicio.

2. Tienen la consideración de instrucciones aquella serie de normas internas dirigidas a establecer pautas o criterios de actuación por las que han de regirse en general las unidades dependientes del órgano que las dicta.

3. Son circulares aquellas normas administrativas internas dictadas por los órganos superiores o directivos y dirigidas a los órganos y unidades que de ellos dependen, encaminadas a recordar la aplicación de determinadas disposiciones legales o indicándoles una interpretación adecuada al espíritu y principios de tales disposiciones con el fin de aplicar en el ámbito de la actuación administrativa una interpretación homogénea de éstas.

4. Las órdenes de servicio son aquellas reglas de actuación u órdenes específicas que se dirigen a un órgano jerárquicamente inferior para un supuesto determinado.

5. Cuando una disposición así lo establezca o en aquellos casos en que se considere conveniente su conocimiento por los ciudadanos o por el resto de los órganos de la Administración de la Comunidad Autónoma, el titular de la Consejería podrá ordenar la publicación de las instrucciones, circulares y órdenes de servicio en el "Diario Oficial de Extremadura»."

Éste es también el caso de la Ley 3/2003, de 26 marzo del Parlament de las Illes Balears, de Régimen jurídico de la administración de la Comunidad Autónoma de las Illes Balears, artículo 21, Instrucciones, circulares y órdenes de servicio:

“1. Los órganos superiores y directivos impulsan y dirigen la actividad administrativa por medio de instrucciones, circulares u órdenes de servicio. 2. Tienen la consideración de instrucciones aquellas reglas internas dirigidas a establecer pautas o criterios de actuación por las cuales se regirán, en general, los órganos y las unidades administrativas dependientes, o aquellos que las tengan que aplicar por razón de la materia o de las tareas que desarrollen.

3. Son circulares aquellas pautas de actuación interna dictadas por los órganos superiores o directivos y encaminadas a recordar la aplicación de determinadas disposiciones legales, o a unificar criterios de interpretación de éstas, con la finalidad de que se aplique en el ámbito de la actuación administrativa una interpretación homogénea.

4. Las órdenes de servicio son mandatos específicos dictados por cualquier órgano de la Administración dirigidas a un órgano jerárquicamente inferior y para un supuesto concreto.

5. Cuando una disposición así lo establezca, o cuando se considere conveniente su conocimiento por los ciudadanos o el resto de órganos de la Administración de la Comunidad Autónoma, el titular de la consejería podrá ordenar la publicación en el "Butlletí Oficial de las Illes Balears" de las instrucciones y circulares."

19 Cabe recordar en este sentido lo que señala el artículo $21.2^{\circ}$ por cuanto su incumplimiento:

"2. El incumplimiento de las instrucciones u órdenes de servicio no afecta por sí solo a la validez de los actos dictados por los órganos administrativos, sin perjuicio de la responsabilidad disciplinaria en que se pueda incurrir."

20 En este sentido, expresamente, la Ley 6/2002, de 10 diciembre del Parlamento de Cantabria, de Régimen Jurídico del Gobierno y de la Administración de la Comunidad Autónoma de Cantabria en su artículo 63. 2 señala que pese a su posible publicación, no son normas reglamentaris: “Instrucciones y órdenes de servicio."2. En concreto, los Secretarios Generales y los Directores Generales podrán dictar instrucciones y órdenes de servicio para dirigir la actividad de las dependencias y servicios a su cargo. Dichas circulares e instrucciones podrán publicarse en el «Boletín Oficial de Cantabria», no constituyendo en ningún caso manifestación del ejercicio de la potestad reglamentaria."

21 Cabe señalar, no obstante, que en la Ley 5/1983, de 30 de diciembre que regula el Gobierno valenciano sí que se incluyen las Instrucciones y órdenes como ("Otras disposiciones") en la prelación de jerarquía de normas (artículo 39), en el último lugar y en dependencia de la jerarquía de quienes las dictan. Estas normas se dictan por "secretarios autonómicos y órganos directivos de la Comunidad Valenciana".

22 En esta dirección, afirma respecto de las circulares e instrucciones, que tienen por fin ordenar y conducir la actividad de lo órganos inferiores en la construcción jerarquizada, de canalizar eficaz y regularmente el impulso y la información desde los niveles superiores. Advierte que pueden tener los más variados contenidos (informativos, interpretativos, preceptivos, etc.). Asimismo, señala que también pueden ser reglas generales y reglas singulares u órdenes de servicio. Y, por lo que ahora interesa, apunta que no sólo son reglas organizativas y directivas de la actividad de los inferiores, sino materialmente equiparables a las reglamentarias. 
reglamentaria ni bajo el procedimiento establecido de aprobación de reglamentos ${ }^{21}$. Pese a no ser reglamentos, para Parejo ${ }^{22}$ o Santamaría (p. 319), en muchos de los casos son verdaderas normas jurídicas. Sin embargo, para el Tribunal Supremo no cabe invocarlas como normas jurídicas (sentencia de 1 de mayo de 2001), aunque en muchos casos examine su contenido y forma para dotarles de una u otra naturaleza ${ }^{23}$. Para el Tribunal Constitucional, hay que estar al contenido de estas órdenes e instrucciones y a la competencia del órgano que las dicta para considerarlas actos administrativos singulares o generales o verdaderas normas reglamentarias, para atribuirles eficacia interna o externa, para exigir su publicación oficial o su mera publicidad en tablones u otros boletines, etc. (sentencia 27/1983, FJ $2^{\circ}$, entre otras $\left.{ }^{24}\right)$.

Por cuanto a su eficacia, no se duda que son de obligatorio cumplimiento ad intra, es decir, para la dependencia administrativa y los subordinados a los que se dirige. Ello se justifica constitucional- mente merced al principio de jerarquía administrativa (art. $103 \mathrm{CE}^{25}$ ). Sin embargo, en teoría su cumplimiento no se puede exigir ad extra, es decir, respecto de los terceros -los administrados-. Ahora bien, el administrado sí que se puede exigir que la Administración cumpla estas circulares e instrucciones en su beneficio. Como señala Garrido Falla, un acto administrativo que desconociese una circular o instrucción sería expresivo de arbitrariedad (art. 9. $3^{\circ} \mathrm{CE}^{26}$ ) o discriminación (art. $14 \mathrm{CE}^{27}$ ). Así pues, no pueden tener eficacia externa, si bien un tercero puede alegar su incumplimiento por la Administración.

Hay que advertir, por último, y para mayor confusión, que muchas de estas "instrucciones" u "órdenes" (terminología ley 30/1992) que, como se ha dicho, no son reglamentos, se autodenominan "circulares". Y el mismo nombre reciben las "Circulares" de administraciones independientes como el Banco de España o la Comisión Nacional del Mercado de Valores ${ }^{28}$. En estos supuestos sí que se trata de normas regla-

23 A la vista de su contenido efectivo el Tribunal Supremo las ha considerado a veces acto administrativo general (sentencias Tribunal Supremo de 13 de julio de 1995 y de 13 de septiembre) o verdadera norma. (sentencias de 30 de mayo, de 28 de septiembre y de 16 de noviembre de 1995). En estos casos se admite su eficacia ad extra por lo que exigen su publicación en los términos de las normas propiamente reglamentarias.

24 En sentencias como las 27/1983, de 20 de abril, la sentencia 249/1988, de 20 de diciembre se ha afirmado que la forma no es criterio que permite determinar la naturaleza de la Circular, y tal calificación ha de realizarse a partir de su contenido, ya se trate de un contenido normativo o de un acto interno" (FJ 20): "La forma de los actos jurídicos de la Administración no es relevante en todos los casos para determinar su naturaleza".... "en cuanto a las circulares instrucciones, pueden ser disposiciones de carácter general... o una manifestación de la potestad jerárquica... que se traduce en un acto que sólo tiene relevancia en el ámbito interno de la Administración", (FJ 2º).

25 Artículo 103: "1. La Administración Pública sirve con objetividad los intereses generales y actúa de acuerdo con los principios de eficacia, jerarquía, descentralización, desconcentración y coordinación, con sometimiento pleno a la ley y al Derecho."

26 La Constitución garantiza el principio de legalidad, la jerarquía normativa, la publicidad de las normas, la irretroactividad de las disposiciones sancionadoras no favorables o restrictivas de derechos individuales, la seguridad jurídica, la responsabilidad y la interdicción de la arbitrariedad de los poderes públicos.

27 Artículo 14: “Los españoles son iguales ante la ley, sin que pueda prevalecer discriminación alguna por razón de nacimiento, raza, sexo, religión, opinión o cualquier otra condición o circunstancia personal o social."

28 Así, en virtud de Ley 13/1994, de 1 de junio, reguladora del Banco de España, o la Ley 24/1998, de 28 de julio que regula la Comisión Nacional del Mercado de Valores. 
mentarias en virtud de la potestad reglamentaria atribuida por las leyes a estas administraciones. También, la Ley 21/2003, de 7 de julio, de Seguridad Aérea habilita al Director General de Aviación Civil para aprobar normas reglamentarias que se publican en el BOE bajo el nombre de "Circulares aeronáuticas", que también son normas reglamentarias.

\subsubsection{Otros reglamentos que nada tienen que ver con los aquí tratados}

Como advertencia previa, cabe recordar que los reglamentos de los que ahora hablamos nada tienen que ver con los "Reglamentos"29 como norma con eficacia directa de la Comunidad Europea $^{30}$, los cuales en la malograda Constitución europea iban a pasar a denominarse "leyes" ${ }^{31}$, pasando los "reglamentos" a un sentido subordinado y ejecutivo más propio ${ }^{32}$.

También hay que distinguir los reglamentos que ahora se estudian de los reglamentos parlamentarios de las cortes, congreso, senado o asambleas autonómicas ${ }^{33}$. Se trata de normas específicas previstas para el ámbito nacional en el artículo $72.1^{\circ} \mathrm{CE}^{34}$, cuyo rasgo más significativo es que se les atribuye el "valor de ley" (un tribunal ordinario no puede revisarlas) o el hecho de que no pueden ser modificados o derogados por una ley, a diferencia de los reglamentos que ahora se estudian. También hay que hacer una clara distinción respecto de los a veces llamados "reglamentos" de asociaciones o sociedades privadas, incluso de relevancia pública como una Federación deportiva.

\section{QUÉ VALOR TIENE UN REGLAMENTO}

\subsection{El rango inferior a la ley}

Se ha hecho popular una frase atribuida al Conde de Romanones, tres veces presidente del Consejo de Ministros con Alfonso XIII: “Dejad que hagan la ley, que yo haré el reglamento". Se hacía referencia a la tan habitual práctica de que el reglamento de desarrollo y aplicación de una ley burlase y adulterase el sentido de la misma. De este modo, el Parlamento que en principio velaba a través de la ley por los derechos y la propiedad de los ciudadanos, quedaba burlado por el Gobierno, con sus reglamentos siempre amenazante de tales derechos y de la propiedad.

Pues bien, una nota esencial del concepto mismo de reglamento es que son normas situadas por debajo de la ley: limitadas, subsidiadas, condicionadas y complementarias de ésta. Recuer-

29 En este punto, a falta del texto constitucional, sigue estando vigente el Tratado constitutivo de la Comunidad Europea (en la versión dada por el tratado de Maastricht de 7 de febrero de 1992), en concreto, en su artículo 249: “Para el cumplimiento de su misión, el Parlamento Europeo y el Consejo conjuntamente, el Consejo y la Comisión adoptarán reglamentos y las directivas tomarán decisiones y formularán recomendaciones o emitirán dictámenes, en las condiciones previstas en el presente Tratado. "El reglamento tendrá un alcance general. Será obligatorio en todos sus elementos y directamente aplicable en cada Estado miembro".

30 Por ejemplo: Reglamento (CE) n 3381/94 del Consejo, de 19 de diciembre de 1994 por el que se establece un régimen comunitario de control de las exportaciones de productos de doble uso.

31 Así, cabe remitir al articulo I-33 del Texto constitucional: "Actos jurídicos de la Unión 1. Las instituciones, para ejercer las competencias de la Unión, utilizarán los siguientes instrumentos jurídicos, de conformidad con la Parte III: la ley europea, la ley marco europea, el reglamento europeo, la decisión europea, las recomendaciones y los dictámenes. La ley europea es un acto legislativo de alcance general. Será obligatoria en todos sus elementos y directamente aplicable en cada Estado miembro."

32 En el referido artículo se definen los reglamentos: "El reglamento europeo es un acto no legislativo de alcance general que tiene por objeto la ejecución de actos legislativos y de determinadas disposiciones de la Constitución. Podrá bien ser obligatorio en todos sus elementos y directamente aplicable en cada Estado miembro, o bien obligar al Estado miembro destinatario en cuanto al resultado que deba conseguirse, dejando, sin embargo, a las autoridades nacionales la competencia de elegir la forma y los medios."

33 Por ejemplo: Reglamento del Congreso de los Diputados, de 10 de febrero de 1982, Reglamento de las Cortes Valencianas, de 30 de junio de 1994.

34 Artículo 72: "1. Las Cámaras establecen sus propios Reglamentos, aprueban autónomamente sus presupuestos y, de común acuerdo, regulan el Estatuto del Personal de las Cortes Generales. Los Reglamentos y su reforma serán sometidos a una votación final sobre su totalidad, que requerirá la mayoría absoluta." 
da de Otto (1987) que las normas con fuerza de ley tienen fuerza activa y pasiva respecto de los reglamentos: una ley puede derogar a un reglamento, pero no puede quedar derogada por éste. Asimismo, en razón de la jerarquía, queda derogado y sin validez cualquier reglamento que se oponga a una ley, decreto-ley o decreto legislativo (en este punto, debe recordarse que estas formas de norma aprobada por decreto por el Gobierno nacional -o en su caso autonómico- tienen fuerza de ley ${ }^{35}$ ). También, el artículo 1. 2 del código civil dispone que "carecerán de validez las disposiciones que contradigan otra de rango superior", la Ley 30/1992 señala que "serán nulas de pleno derecho las disposiciones administrativas que vulneren la Constitución, las leyes u otras disposiciones administrativas de ran- go superior" (Art. 62. 20, también Art. $51^{36}$ ), también, la Ley del Gobierno (Art. 23. $3^{\circ}$ y $\left.4^{\circ}\right)^{37}$. Se trata de nulidad de pleno derecho, ex lege, sin la necesidad de declaración expresa. No obstante, no es tan sencillo determinar cuándo un reglamento pervierte el sentido de la ley que desarrolla o ejecuta. Y cabe adelantar que, en ocasiones, converge la aplicación del principio de jerarquía normativa con el principio de reserva de ley, puesto que la posible vulneración de la ley por el reglamento provendrá de excesos en su desarrollo o ejecución de una ley.

Cabe mencionar algunos fenómenos con conexión con el tema, como la llamada "congelación del rango": si una materia ha pasado a ser regulada por ley, el rango queda congelado y en

35 La regulación constitucional de estos tipos de norma viene dada en los artículos 82 y 86:

Artículo 82 "1. Las Cortes Generales podrán delegar en el Gobierno la potestad de dictar normas con rango de ley sobre materias determinadas no incluidas en el artículo anterior.

2. La delegación legislativa deberá otorgarse mediante una ley de bases cuando su objeto sea la formación de textos articulados o por una ley ordinaria cuando se trate de refundir varios textos legales en uno solo.

3. La delegación legislativa habrá de otorgarse al Gobierno de forma expresa para materia concreta y con fijación del plazo para su ejercicio. La delegación se agota por el uso que de ella haga el Gobierno mediante la publicación de la norma correspondiente. No podrá entenderse concedida de modo implícito o por tiempo indeterminado. Tampoco podrá permitir la subdelegación a autoridades distintas del propio Gobierno

4. Las leyes de bases delimitarán con precisión el objeto y alcance de la delegación legislativa y los principios y criterios que han de seguirse en su ejercicio.

5. La autorización para refundir textos legales determinará el ámbito normativo a que se refiere el contenido de la delegación, especificando si se circunscribe a la mera formulación de un texto único o si se incluye la de regularizar, aclarar y armonizar los textos legales que han de ser refundidos. 6. Sin perjuicio de la competencia propia de los Tribunales, las leyes de delegación podrán establecer en cada caso fórmulas adicionales de control." Artículo 85: "Las disposiciones del Gobierno que contengan legislación delegada recibirán el título de Decretos Legislativos."

Artículo 86: "1. En caso de extraordinaria y urgente necesidad, el Gobierno podrá dictar disposiciones legislativas provisionales que tomarán la forma de Decretos-leyes y que no podrán afectar al ordenamiento de las instituciones básicas del Estado, a los derechos, deberes y libertades de los ciudadanos regulados en el Título I, al régimen de las Comunidades Autónomas ni al Derecho electoral general.

2. Los Decretos-leyes deberán ser inmediatamente sometidos a debate y votación de totalidad al Congreso de los Diputados, convocado al efecto si no estuviere reunido, en el plazo de los treinta días siguientes a su promulgación. El Congreso habrá de pronunciarse expresamente dentro de dicho plazo sobre su convalidación o derogación, para lo cual el reglamento establecerá un procedimiento especial y sumario.

3. Durante el plazo establecido en el apartado anterior, las Cortes podrán tramitarlos como proyectos de ley por el procedimiento de urgencia."

Artículo 51. Jerarquía y competencia: "1. Las disposiciones administrativas no podrán vulnerar la Constitución o las Leyes ni regular aquellas materias que la Constitución o los Estatutos de Autonomía reconocen de la competencia de las Cortes Generales o de las Asambleas Legislativas de las Comunidades Autónomas.

2. Ninguna disposición administrativa podrá vulnerar los preceptos de otra de rango superior.

3. Las disposiciones administrativas se ajustarán al orden de jerarquía que establezcan las leyes."

Artículo 62. Nulidad de pleno derecho: “[...] 2. También serán nulas de pleno derecho las disposiciones administrativas que vulneren la Constitución, las leyes $\mathrm{u}$ otras disposiciones administrativas de rango superior, las que regulen materias reservadas a la Ley, y las que establezcan la retroactividad de disposiciones sancionadoras no favorables o restrictivas de derechos individuales."

37 Ley 50 /1997, de 27 de noviembre, del Gobierno, artículo 23. De la potestad reglamentaria: "3. [...] Ningún reglamento podrá vulnerar preceptos de otro de jerarquía superior.

4. Son nulas las resoluciones administrativas que vulneren lo establecido en un reglamento, aunque hayan sido dictadas por órganos de igual a superior jerarquía que el que lo haya aprobado." 
el futuro sólo por ley se podrá alterar dicha regulación, no por reglamento. Ello no obsta, como se dirá, las posibilidades de desarrollo o ejecución reglamentaria de dicha materia regulada por la ley, pero sin oposición o alteración de ésta y en el margen que la misma ley permita al reglamento.

Como fenómeno anverso, también puede hablarse de la figura de la deslegalización. Una materia que estaba regulada por ley deja de estarlo. ¿Cómo? En virtud de una ley posterior que deslegaliza la cuestión remitiéndola, por ejemplo, al desarrollo por reglamento ("el gobierno reglamentariamente fijará las condiciones para el reconocimiento del derecho de prestación para caso de partos múltiples" -si es que anteriormente estas condiciones venían reguladas por ley). La consecuencia es que esta materia podrá ser regulada en el futuro por reglamento, y no necesariamente por ley. Ahora bien, no siempre es constitucionalmente admisible la deslegalización, puesto que queda sometida a los límites de las diversas reservas de ley establecidas en la Constitución, así como a las prohibiciones constitucionales de habilitaciones en blanco. Se trata de una materia compleja que hay que analizar caso por caso.

Hay casos específicos, y ciertamente curiosos, de deslegalización: cuando una ley mantiene en vigor una ley anterior, pero la relega expresamente a carácter reglamentario, por lo que reglamentos posteriores pueden pasar a modificar o derogar lo que originariamente era una ley ${ }^{38}$.

\subsection{El rango entre los reglamentos}

El principio de jerarquía normativa (Art. 9. $3^{\circ} \mathrm{CE}$, art. 1. $1^{\circ}$ Código Civil) no sólo se aplica entre ley y reglamento, sino, también, entre los reglamentos mismos a partir del principio administrativo de jerarquía (Art. $103 \mathrm{CE}$ ). La prelación entre reglamentos entronca directamente con la ordenación jerárquica entre los órganos de los que emana (por ejemplo, reales decretos del consejo de ministros sobre órdenes ministeriales, Art. 23. $3^{\circ}$ Ley del Gobierno ${ }^{39}$ ). Así, la forma y procedencia del reglamento es el dato fundamental para determinar su jerarquía ${ }^{40}$.

Cabe señalar con Montilla (2002) que se encuentran en el mismo nivel jerárquico los reglamentos aprobados por el Consejo de Ministros que los del presidente del Gobierno (ambos por Real Decreto), bien que podría no ser así y haberse subordinado los del Presidente a los del Consejo de Ministros.

Un ejemplo claro de ordenación jerárquica -incluso excesivo ${ }^{41}$ - para el ámbito autonómico ${ }^{42}$,

38 Por ejemplo, la Disposición derogatoria única de Ley 17/1999, de 18 de mayo, de régimen del personal de las Fuerzas Armadas dispone que la Ley 50/1969, de 26 de abril, básica de Movilización Nacional, continuará en vigor con carácter reglamentario, en lo que no se oponga a lo previsto en la presente Ley

39 En el ámbito estatal, Ley 50 /1997, de 27 de noviembre, del Gobierno, artículo 23. De la potestad reglamentaria. [...] 3. Los reglamentos se ajustarán a las siguientes normas de competencia y jerarquía:

$1^{\circ}$ Disposiciones aprobadas por Real Decreto del Presidente del Gobierno o del Consejo de Ministros.

$2^{\circ}$ Disposiciones aprobadas por Orden Ministerial.

Ningún reglamento podrá vulnerar preceptos de otro de jerarquía superior.

4. Son nulas las resoluciones administrativas que vulneren lo establecido en un reglamento, aunque hayan sido dictadas por órganos de igual a superior jerarquía que el que lo haya aprobado."

40 Las normas autonómicas también regulan la jerarquía, normalmente entre "Decretos" $y$ "Órdenes", sin otra distinción, si bien, como se señalaba en nota supra, hay casos en los que se relacionan jerárquicamente distintos instrumentos normativos: Decretos del Gobierno Valenciano, Decretos del Presidente, Órdenes de las Comisiones Delegadas, Órdenes de las Consellerías. Ver, Ley 5/1983, de 30 de diciembre que regula el Gobierno valenciano.

41 Se hace referencia, como se señalaba supra, a la inclusión final de "Otras disposiciones", que, como arriba se decía, se trata de las Instrucciones y Órdenes de órganos inferiores a los anteriores (Secretarios Autonómicos y Directores Generales)

42 Salvo este caso, por lo general las normas autonómicas únicamente distinguen entre "Decretos" y "Órdenes". 
nos lo brinda la Ley 5/1983, de 30 de diciembre, de gobierno valenciano: En su artículo 39, dispone que "las normas que sean consecuencia del ejercicio de la potestad reglamentaria se ajustan a la siguiente jerarquía: 1 . Decretos del gobierno; 2 . decretos del presidente; 3 . ordenes de las comisiones delegadas del gobierno; 4 . órdenes de Consellerías; 5 . disposiciones de órganos inferiores por el orden de su jerarquía".

Amén del principio de jerarquía, habrá que estar también por el principio de competencia u otros criterios ante supuestos particulares de posible colisión de normas reglamentarias, en especial, por cuanto a su procedencia de ámbitos no vinculados jerárquicamente (por ejemplo, una Orden de un Conseller autonómico y un Real Decreto del Presidente del Gobierno; una Ordenanza municipal y una circular del Banco de España) En este sentido hay que tener en cuenta la procedencia de la potestad reglamentaria atribuida (constitucional, legal, etc.), su alcance y competencia, su función y naturaleza (municipal, administración independiente, órgano constitucional, etc.), y otros elementos caso por caso. Bien es cierto que, en ocasiones los conflictos pueden darse entre en el ámbito del mismo complejo gobierno-administración (dos Órdenes de Ministros o Consejeros de distintos ramos, incluso entre los Decretos del Presidente del Gobierno y el Consejo de Gobierno) ${ }^{43}$.

\section{QUÉ PUEDE SER REGULADO POR REGLAMENTO}

\subsection{Qué materias puede regular un reglamento}

En España, a diferencia de la vecina Francia, no existe ninguna suerte de reserva reglamentaria ${ }^{44}$, esto es, la Constitución no veda al legislador la regulación de ciertas materias reservándolas al reglamento. Así, en la Constitución española la naturaleza de reglamento no queda en nada vinculada con la materia que regula. En este sentido, es "reglamento" la norma dictada por el Gobierno y/o Administración correspondiente que ejerce la potestad reglamentaria que tenga reconocida y lo haga siguiendo el procedimiento establecido, sea cual sea la materia de la que se ocupe.

\subsection{Límites al contenido de los reglamentos: especial atención a la reserva de ley}

Lo anterior no quiere decir que no haya límites lo que puede ser regulado por un reglamento. De hecho, ésta es una materia tan compleja como esencial para el Derecho constitucional, que entronca con cuestiones capitales como la división de poderes y los límites del Ejecutivo y a la acción misma del legislador, la reserva -o más bien, reservas- de ley y el principio de legalidad.

43 En el caso mencionado de la Ley de gobierno valenciano queda clara la prelación del órgano de gobierno sobre los Decretos del Presidente, sin embargo, ello no es así en muchas normas autonómicas o en el mismo artículo $23.3^{\circ}$ de la Ley de Gobierno estatal, que los sitúan de forma pareja. En este punto, lo propio es acudir a las normas de competencia y atribución interna.

44 Así, la Constitución de Francia, de 4 de octubre de 1958, en su artículo 34, determina lo que ha de ser regulado por ley votada por el Parlamento. Por su parte, el artículo 37 dispone que "las materias distintas a las que pertenecen al ámbito de la ley, tendrán carácter reglamentario". Añadiéndose que "Ios textos sobre estas materias que tengan forma de ley, podrán ser modificados por decretos adoptados previo dictamen del Consejo de Estado. Los textos con tal carácter que se dicten después de la entrada en vigor de la presente Constitución, sólo podrán ser modificados por decreto, si el Consejo Constitucional declarase que poseen carácter reglamentario en virtud de lo dispuesto en el párrafo anterior". 
Así, la premisa es que por el principio de jerarquía antes visto, un reglamento no puede derogar ni modificar el contenido de normas con fuerza de ley ni de reglamentos jerárquicamente superiores. El problema es que no es tan sencillo determinar cuándo un reglamento pervierte el sentido de la ley que desarrolla o aplica. Pese a tratarse de una cuestión de aplicación del principio de jerarquía, en ocasiones la misma ha de observarse desde la reserva de ley, puesto que la posible conculcación provendrá de excesos del reglamento respecto de la ley.

Asimismo, la reserva de ley fue una garantía en el marco de la pugna decimonónica entre el poder monárquico del Gobierno (no democrático) frente al soberano parlamentario (democrático). El ejecutivo sólo actuaba previa habilitación del legislativo. De este modo, y para mayor garantía, las constituciones recogieron expresamente ámbitos en los que la regulación había de ser de rango legal, confiriendo mayor o menor posibilidad de actuación al reglamento y siempre supeditado a la ley. Así, en nuestra Constitución podemos observar numerosas reservas de ley expresas:
- $\quad$ Reservas generales como las de los artículos $53^{45} \mathrm{u} 81^{46} \mathrm{CE}$, respecto de los derechos fundamentales, con mayor o menor intensidad y con reservas de ley concretas.

- Espacios intensamente reservados a la ley, como el ámbito penal y disciplinario (Art. 25 principio de legalidad ${ }^{47}$ y art. 17 CE respecto de la libertad personal ${ }^{48}$ ), así como la tan importante reserva tributaria del artículo $31.3^{\circ} \mathrm{CE}^{49}$.

- $\quad$ Asimismo, es posible observar muy numerosas reservas de ley, particulares a lo largo de todo el texto sobre las materias más variadas, bien para regulación por ley ordinaria ${ }^{50}$, ya por regulación por ley orgánica ${ }^{51}$.

- En ocasiones, estas reservas son muy genéricas, perdiendo mucha intensidad la obligación de que sea la ley la que regule, ampliando, por tanto, las posibilidades de actuación del reglamento. Así, por ejemplo, la reserva de ley del artículo 103. $2^{\circ} \mathrm{CE}$ : "Los órganos de la administración del Estado son creados, regidos y coordinados de acuerdo con la ley", que confi-

45 Artículo 53: "1. Los derechos y libertades reconocidos en el Capítulo segundo del presente Título vinculan a todos los poderes públicos. Sólo por ley, que en todo caso deberá respetar su contenido esencial, podrá regularse el ejercicio de tales derechos y libertades, que se tutelarán de acuerdo con lo previsto en el artículo 161, 1, a)."

46 Artículo 81: "1. Son leyes orgánicas las relativas al desarrollo de los derechos fundamentales y de las libertades públicas, las que aprueben los Estatutos de Autonomía y el régimen electoral general y las demás previstas en la Constitución."

47 Artículo 25: "1. Nadie puede ser condenado o sancionado por acciones u omisiones que en el momento de producirse no constituyan delito, falta o infracción administrativa, según la legislación vigente en aquel momento."

48 Artículo 17: "1. Toda persona tiene derecho a la libertad y a la seguridad. Nadie puede ser privado de su libertad, sino con la observancia de lo establecido en este artículo y en los casos y en la forma, previstos en la ley.

2. La detención preventiva no podrá durar más del tiempo estrictamente necesario para la realización de las averiguaciones tendentes al esclarecimiento de los hechos, y, en todo caso, en el plazo máximo de setenta y dos horas, el detenido deberá ser puesto en libertad o a disposición de la autoridad judicial.

3. Toda persona detenida debe ser informada de forma inmediata, y de modo que le sea comprensible, de sus derechos y de las razones de su detención, no pudiendo ser obligada a declarar. Se garantiza la asistencia de abogado al detenido en las diligencias policiales y judiciales, en los términos que la ley establezca.

4. La leyregulará un procedimiento de habeas corpus para producir la inmediata puesta a disposición judicial de toda persona detenida ilegalmente. Asimismo, por leyse determinará el plazo máximo de duración de la prisión provisional."

49 Artículo 31 [...] 3. Sólo podrán establecerse prestaciones personales o patrimoniales de carácter público con arreglo a la ley."

50 Son muchísimas, a título de ejemplo, artículo 51. $3^{\circ}$ la ley regulará el comercio interior y el régimen de autorización de productos comerciales.

51 Sin perjuicio del general artículo $81 \mathrm{CE}$, son más de treinta las reservas particulares de ley orgánica, como, por ejemplo, artículo 8 . $2^{\circ}$ : “Una ley orgánica regulaŕ las bases de la organización militar conforme a los principios de la presente Constitución"; artículo 54 : “Una ley orgánica regulará la institución del Defensor del Pueblo"; artículo 57. 5: "El orden de sucesión a la Corona, se resolverán por una ley orgánica". 
guran a la postre un ámbito típico de actuación reglamentaria con mucha libertad respecto de lo dispuesto por la ley".

La reserva de ley es una categoría que, ciertamente, se proyecta caso por caso, materia por materia, variando en razón tanto del texto constitucional cuanto del cambiante entendimiento doctrinal y jurisprudencial (García, 1987; Baño León, 1991). Es una cuestión básicamente de intensidades que han de ser determinadas jurisprudencialmente en el control de la actuación del normador reglamentario. Incluso en ámbitos, con una reserva de ley intensa, como el principio de legalidad penal y disciplinario o la libertad personal $u$ otros derechos fundamentales la reserva se relaja bastante si se trata de una de las llamadas "relaciones de especiales de sujeción" (López, 1994). Estas relaciones son como las que la Administración, como las que tiene un alumno con una universidad pública, un preso con la institución penitenciaria, un funcionario con la administración en la que sirve, etc. En estos casos, existe la reserva de ley, pero se suele conferir espacios de regulación al reglamento mucho más amplios que en las relaciones de supremacía general (como por ejemplo, la regulación del impuesto de la renta de las personas físicas).

La reserva de ley es una garantía no sólo frente al poder ejecutivo, sino, también, frente al legislador mismo, imponiéndole límites a la hora de hacer remisiones y habilitaciones a la regulación reglamentaria, de modo que no sean excesivamente genéricas o en blanco. También la ley limita la posibilidad de que la ley deslegalice ámbitos otorgando total libertad a la regulación reglamentaria. No es sencillo determinar los límites y márgenes de actuación del reglamento en esta colaboración con la ley, hay que estar a cada caso concreto y la casuística es enorme. Sin perjuicio de ello pueden seguirse algunos criterios generales, como los referidos por Balaguer (1992) y Montilla (2002):

- La reserva de ley no puede significar la obligación del legislador de regular hasta el último detalle sobre una materia. Por ley deben quedar fijados los elementos fundamentales del ámbito regulado y el marco de derechos de los ciudadanos al respecto.

- $\quad$ La ley debe ser suficiente para que un ciudadano pueda conocer sus facultades y obligaciones en la materia reservada a la ley, los reglamentos para conocer el modo en que puede ejercitar estas facultades y cumplir esas obligaciones.

- En el ámbito de una reserva de ley, el reglamento puede tanto desarrollar la misma para hacer posible su ejecución, así como integrar vacíos normativos que impidan la aplicación de la ley.

Resulta casi didáctico el artículo 23. 20, de la Ley del Gobierno, cuando señala unos ámbitos más sensibles, donde las posibilidades de actuación por reglamento van a ser muy limitadas y la sumisión del reglamento a la ley de la máxima intensidad:

Los reglamentos no podrán regular materias objeto de reserva de ley, ni infringir normas con dicho rango. Además, sin perjuicio de su función de desarrollo o colaboración con respecto a la ley, no podrán tipificar delitos, faltas o infracciones administrativas, establecer penas o sanciones, así como tributos, cánones u otras cargas o prestaciones personales o patrimoniales de carácter público.

En esta línea, el Tribunal Constitucional ha señalado que en materia de derechos fundamentales donde hay una reserva intensa, las posibilidades de remisión de la ley al reglamento ha de 
limitarse a aspectos "instrumentales" o simples "cuestiones de detalle" (sentencia Tribunal Constitucional 77/1985).

Las dudas se pueden suscitar desde diversos planos y para su explicación resulta útil acudir a la tipología de reglamentos usualmente establecida, como se lleva a cabo a continuación.

\subsection{Reglamentos de desarrollo y reglamentos independientes}

\subsubsection{Reglamentos de desarrollo o ejecución}

El legislador se concentra en lo general, principal y perdurable, descargándose de lo segundario, particular y mudable en el ejecutivo para que lo adapte a la realidad y el tiempo donde la ley debe aplicarse por medio de estos reglamentos. Son los Ilamados reglamentos de desarrollo o ejecución de la ley, también denominados secundum legem $^{52}$. En estos casos es donde se da especialmente el fenómeno de la colaboración del reglamento con la ley, completando y detallando la regulación legal, adecuándola a la realidad donde se ha de aplicar y a cada momento. Son del todo habituales al punto de que hay leyes que sin su desarrollo reglamentario quedarían casi inaplicadas.

Hay que advertir que resulta muy típico el empleo en una disposición final de una ley de la expresión "se autoriza al Gobierno para dictar cuantas disposiciones sean necesarias para la aplicación de la presente ley". Como recuerda de Otto, estas expresiones inducen erróneamente a pensar que si la ley no "autorizase" al Gobierno, éste no podría éste desarrollar la ley con el reglamento (De Otto, 1987, p.235). Sin embargo, al reglamento sólo le está vedado lo que está sometido a reserva de ley, por lo que estas habilitaciones generales no son necesarias. Las que sí tienen sentido son las remisiones y habilitaciones concretas de la ley al reglamento señalando los ámbitos que debe abordar el reglamento, indicando no sólo lo que sí debe regular, sino orientando cómo hacerlo ${ }^{53}$.

Al respecto de las posibilidades y límites de la colaboración del reglamento de ejecución o desarrollo con la ley, pueden exponerse algunos criterios:

- $\quad$ los "elementos fundamentales" de una materia siempre corresponden a la ley, lo secundario pero necesario para la puesta en práctica de la Ley, puede ser desarrollado por el reglamento (Tribunal Supremo, 1997, Sentencias de 18 de enero y 7 de abril).

- El reglamento tiene un margen de innovación respecto de la ley que desarrolla o ejecuta: puede hacer explícitas reglas que están simplemente enunciadas en la ley; aclarar preceptos de la ley imprecisos o cubrir vacíos normativos que dificulten o impidan la aplicación de la ley. Así pues, el reglamento puede ir más allá de ser mero ejecutor de la ley (Tribunal Supremo, 1997, Sentencias de 18 de enero y 7 de abril ). Sin embargo esta

52 Por ejemplo, Real Decreto 1775/2004, de 30 de julio, por el que se aprueba el Reglamento del Impuesto sobre la Renta de las Personas Físicas o el Real Decreto 864/2001, de 20 de julio, por el que se aprueba el Reglamento de ejecución de la Ley Orgánica 4/2000, de 11 de enero, sobre derechos y libertades de los extranjeros en España y su integración social.

53 Así, por ejemplo:

"Reglamentariamente, se determinarán las categorías de datos que deberán conservarse según el tipo de servicio prestado, el plazo durante el que deberán retenerse en cada supuesto dentro del máximo previsto en este artículo, las condiciones en que deberán almacenarse, tratarse y custodiarse y la forma en que, en su caso, deberán entregarse a los órganos autorizados para su solicitud y destruirse, transcurrido el plazo de retención que proceda, salvo que fueran necesarios para estos u otros fines previstos en la Ley."

“En el desarrollo reglamentario del Título XIII de esta Ley, se establecerá el régimen de integración como reservistas voluntarias de las componentes de la Agrupación de Damas Auxiliares de Sanidad Militar, que será de aplicación a quien solicite su integración como reservista voluntaria." 
capacidad de innovación está limitada: “El gobierno no puede crear derechos ni imponer obligaciones que no tengan su origen en la ley, de modo inmediato o mediato, a través de la habilitación. Del mismo modo, no puede el Reglamento excluir del goce de un derecho a aquellos a quienes la ley no excluyó" ${ }^{54}$.

- Tampoco puede aprovecharse el desarrollo reglamentario de una ley para desbordar el ámbito del grupo normativo que le es propio y resolver problemas ajenos a este ámbito ${ }^{55}$.

- $\quad$ Las posibilidades de actuación e innovación del reglamento son muy limitadas en ámbitos sensibles. Así, como reza la antecitada Ley del Gobierno, los reglamentos "no podrán tipificar delitos, faltas o infracciones administrativas, establecer penas o sanciones, así como tributos, cánones u otras cargas o prestaciones personales o patrimoniales de carácter público" (Art. 23. 2). En esta línea, el Tribunal Constitucional ha señalado que en materia de derechos fundamentales donde hay una reserva intensa, las posibilidades de remisión de la ley al reglamento ha de limitarse a aspectos "instrumentales" o simples "cuestiones de detalle"56.

\subsubsection{Los polémicos reglamentos independientes}

A diferencia de los reglamentos secundum legem, de ejecución o desarrollo de una ley, resultan especialmente polémicos los reglamentos praeter legem, esto es, los dictados al margen de la ley pero sin contradecir ninguna, en materias en las que no pesa una reserva de ley. Surge en este sentido la cuestión de la admisibilidad constitucional de dictar reglamentos "indepen- dientes" de una ley. Siguiendo a Santamaría (2002, p. 349), estos reglamentos no son extraños en el ámbito del derecho de autoorganización de la Administración (a partir de la muy genérica reserva de ley del artículo 103. $2^{\circ}\left(E^{57}\right)$, en el ámbito de las relaciones de especial sujeción (donde, como antes se señalaba, se relaja mucho el principio de legalidad y las diferentes reservas de ley) así como la regulación de actividad prestacional de la Administración y en el derecho de policía.

Sin pronunciamiento concreto del Tribunal Constitucional al respecto, el Tribunal Supremo dijo en su sentencia de 1 de abril de 1981 que:

La potestad reglamentaria de la Administración en la actualidad reconocida en el artículo 97 de la Constitución opera con mayor o menor autonomía según que se ejerza ad intra (es decir, con fines puramente auto-organizativos o en el marco de las relaciones de sujeción especial) o ad extra (lo que sucede cuando regula abstractamente derechos y obligaciones de los ciudadanos en situación de sujeción general), pues en el primer caso podrán dictarse los denominados reglamentos independientes, que son aquellos que no se fundan en una previa habilitación legal y rigen en el ámbito interno o doméstico de la Administración, en tanto que en el segundo nos encontraremos ante los reglamentos ejecutivos, caracterizados porque desarrollan una ley previa, en ausencia de la cual no puede la Administración proceder a su elaboración.

Así pues, la también clásica distinción de reglamentos jurídicos normativos (ad extra) y reglamentos administrativos o de organización (ad intra) parece proyectarse como criterio de

54 Sentencia del Tribunal Constitucional 209/1987, de 22 de diciembre, FJ $3^{\circ}$.

55 Por ejemplo, el reglamento de extranjería no tiene que regular las relaciones Iglesia-Estado, así lo afirma el Tribunal Supremo, sentencias de 18 de enero y 7 de abril de 1997.

56 Sentencia 77/1985, del Tribunal Constitucional.

57 “2. Los órganos de la Administración del Estado son creados, regidos y coordinados de acuerdo con la ley". 
admisibilidad de los reglamentos independientes. Esta posición se ha mantenido en sentencias de 27 de marzo de 1985, de 31 de octubre de 1986, 27 de febrero de 1997, por ejemplo. No obstante, en la sentencia del Tribunal Supremo de 28 de enero 1997, se manejó un concepto algo más amplio de reglamento independiente, admitiéndolos no sólo estrictamente al ámbito ad intra ${ }^{58}$. La cuestión es una cuestión abierta y polémica, que incluso adquiere tonos más complejos cuando se trata de las normas estatutarias o reglamentarias de los entes locales, que no suelen ser desarrollo de una ley, sino simplemente permitidas por ésta.

\section{QUIÉNES PUEDEN APROBAR REGLAMENTOS Y QUÉ NOMBRE RECIBEN}

\subsection{Reglamentos en sentido estricto: del Gobierno de la nación y de los gobiernos autonómicos}

La potestad reglamentaria, el poder de dictar reglamentos, puede atribuirse originariamente por la Constitución -de forma más o menos indirectaasí como puede hablarse de una potestad reglamentaria derivada, a partir de la ley, con mayor o menor fundamentación constitucional. El ejemplo más claro de potestad originaria directa lo establece el artículo $97 \mathrm{CE}$, relativo al Gobierno de la Nación, cuando afirma que "El Gobierno [...] Ejerce la función ejecutiva y la potestad reglamentaria de acuerdo con la Constitución y las leyes".

El reconocimiento constitucional de esta potestad es directo y originario cuando se trata del órgano colegiado, el Consejo de Ministros (reforzado por el art. 62 f) $\mathrm{CE})^{59}$, expresado luego en la Ley de Gobierno ${ }^{60}$. Sin embargo, la potestad reglamentaria de los componentes individuales del Gobierno (art. 98. $1^{\circ} \mathrm{CE}^{61}$ ) no es originaria, sino permitida por la Constitución y realizada a través de la ley (Ley del Gobierno ${ }^{62}$ ), reconociéndose así al presidente, a los ministros y a las comisiones delegadas del gobierno. El Tribunal Constitucional ha entendido que esta potestad de los miembros del gobierno surge de una comprensión no estricta, "al pie de la letra" del artículo 97 CE (Sentencia, 1992, 135, FJ 30).

Así las cosas, para el caso Estatal, en virtud del artículo 25 de la Ley del Gobierno se aprueban reglamentos por medio de Real Decreto, bien del Consejo de Ministros ${ }^{63}$, bien del Presidente ${ }^{64}$. Con rango jerárquico inferior a éstos, por medio

58 En la sentencia se permite la regulación por reglamento independiente de ámbitos no sujetos a reserva de ley para regular todo lo relativo a la organización administrativa, así como para regular el ejercicio de poderes que a la Administración les estén conferidos discrecionalmente. En todo caso, esta sentencia indicó como límites, que esto reglamento independientes "no pueden derogar ni modificar el contenido de una Ley, ni el contenido de otros reglamentos de mayor jerarquía, ni limitar derechos subjetivos ni situaciones jurídicas adquiridas".

59 Este precepto, cabe recordar, señala que "Corresponde al Rey: [...] f) Expedir los decretos acordados en el Consejo de Ministros".

60 Artículo 5. Del Consejo de Ministros: "h) Aprobar los reglamentos para el desarrollo y la ejecución de las leyes, previo dictamen del Consejo de Estado, así como las demás disposiciones reglamentarias que procedan."

61 "1. El Gobierno se compone del Presidente, de los Vicepresidentes, en su caso, de los Ministros y de los demás miembros que establezca la ley." No se contiene alusión ni personalización alguna de la potestad atribuida en el artículo 97.

62 Artículo 4. De los Ministros: "1. Los Ministros, como titulares de sus Departamentos. tienen competencia y responsabilidad en la esfera específica de su actuación, y les corresponde el ejercicio de las siguientes funciones: [...]

b) Ejercer la potestad reglamentaria en las materias propias de su Departamento."

63 Artículo 25. c) "Reales Decretos acordados en Consejo de Ministros, las decisiones que aprueben normas reglamentarias de la competencia de éste y las resoluciones que deban adoptar dicha forma jurídica." También, "d) Acuerdos del Consejo de Ministros, las decisiones de dicho órgano colegiado que no deban adoptar la forma de Real Decreto."

64 Para "Crear. modificar y suprimir, por Real Decreto, los Departamentos Ministeriales, así como las Secretarías de Estado. Asimismo, le corresponde la aprobación de la estructura orgánica de la Presidencia del Gobierno", art. 2. 2j) Ley del Gobierno.

En el artículo 25 b) sobre la forma afirma: “b) Reales Decretos del Presidente del Gobierno las disposiciones y actos cuya adopción venga atribuida al Presidente." 
de "Órdenes" se aprueban normas reglamentarias de los Ministros "en las materias propias de su Departamento" (si son varios los ministerios implicados, la Orden es del Ministerio de la Presidencia) ${ }^{65}$. También pueden aprobarse normas reglamentarias a través de los Acuerdos de las Comisiones Delegadas del Gobierno ${ }^{66}$. Tales acuerdos "revestirán la forma de Orden del Ministro competente o del Ministro de la Presidencia, cuando la competencia corresponda a distintos ministros" ${ }^{\prime \prime}$.

Los decretos son "reales" (Real Decreto) sólo en el caso de los dictados por el Gobierno de la Nación, sin recibir esta nomenclatura los decretos autonómicos. No hace falta subrayar que el Jefe de Estado en modo alguno tiene reconocida potestad reglamentaria, sino que únicamente le corresponde "expedir los decretos acordados en el Consejo de Ministros" (Art. 62 f) CE). EI rey sanciona todos los reglamentos aprobados por Real Decreto (curiosamente, incluso los que no son del Consejo de Ministros, sino del presidente). Por el contrario, el monarca no sanciona aquellos reglamentos aprobados por medio de "orden", puesto que de ellos no habla el artículo 62 f) CE.

Hay que advertir que una de las dificultades que presentan los reglamentos es que no es siempre sencillo identificarlos. Un Real Decreto bien puede ser una norma con fuerza de ley de las antes estudiadas (Real Decreto legislativo o Real Decreto-Ley, si bien cuando se habla de ellos gene- ralmente se prescinde de "real"). Asimismo, y ordenados ya con la misma numeración, un Real Decreto puede ser:

- Una norma reglamentaria ${ }^{68}$.

- En ocasiones, el Real Decreto aprueba expresamente un, así calificado, reglamento anexo al mismo ${ }^{69}$.

- Y lo que es más importante, un Real Decreto y compartiendo la numeración correlativa de reglamentos como los anteriores, bien puede ser un acto singular de nombramiento de un cargo, una concesión de medalla, un indulto o una convocatoria de elecciones, por ejemplo. En estos casos, no estamos ante un reglamento, pese a compartir esta forma de aprobación y la numeración de Real Decreto.

Lo dicho respecto de los reales decretos, vale también respecto de las órdenes ministeriales (una orden puede ser un reglamento o no).

Los gobiernos autonómicos también tienen potestad reglamentaria, que se determina en razón de sus respectivos estatutos de autonomía, desarrollados por sus leyes de gobierno y administración ${ }^{70}$. Al respecto de esta potestad reglamentaria, el Tribunal Constitucional ha señalado que "es consecuencia de la autonomía política de que éstas [las Comunidades Autónomas] gozan, que supone el reconocimiento de una

65 Artículo 25 Ley del Gobierno "f) Órdenes Ministeriales, las disposiciones y resoluciones de los Ministros. Cuando la disposición o resolución afecte a varios Departamentos revestirá la forma de Orden del Ministro de la Presidencia, dictada a propuesta de los Ministros interesados."

66 Articulo 25: “e) Acuerdos adoptados en Comisiones Delegadas del Gobierno, las disposiciones y resoluciones de tales órganos colegiados. Tales acuerdos revestirán la forma de Orden del Ministro competente o del Ministro de la Presidencia, cuando la competencia corresponda a distintos Ministros."

67 Así, artículo 25 Ley del Gobierno, por ejemplo: Orden PRE/2573/2003, de 17 de septiembre, por la que se dispone la publicación del Acuerdo de 4 de septiembre de 2003, de la Comisión Delegada del Gobierno para Asuntos Económicos, por el que se establece el procedimiento para la concesión de avales del Estado a operaciones de inversión destinadas a la adquisición de buques por empresas navieras domiciliadas en España. Por ejemplo: Real Decreto 799/2005, de 1 de julio, por el que se regulan las inspecciones generales de servicios de los departamentos ministeriales.

69 Por ejemplo, Real Decreto 1428/2003, de 21 de noviembre, por el que se aprueba el Reglamento General de Circulación, para la aplicación y desarrollo del texto articulado de la Ley sobre Tráfico, Circulación de Vehículos a Motor y Seguridad Vial.

70 Así, se ha hecho referencia a algunas de ellas en diversos casos. 
potestad legislativa en el ámbito de sus competencias $y$, en general, de amplias facultades de autogobierno, uno de cuyos instrumentos es la posibilidad de ejercer la potestad reglamentaria, también, naturalmente, en ámbito de sus competencias" (Sentencia 108/1986, de 29 de julio, FJ $23^{\circ}$ ). Asimismo, el artículo 153 c) CE parte de la premisa de la potestad reglamentaria en el ámbito autonómico ${ }^{71}$. No en vano, quien puede lo más, puede lo menos. $Y$ es que en el ámbito de las normas del gobierno con valor de ley, se han reproducido en el nivel autonómico los decretos legislativos y los decretos-ley constitucionalmente sólo expresados para el ámbito autonómico.

El nombre de los reglamentos autonómicos podría variar según el marco estatutario y legal concreto, si bien, lo normal es que las normas se denominen "decretos del Gobierno"72 o del Presidente, "Órdenes" bien de las Comisiones Delegadas del Gobierno autonómico o de las Consejerías, o Consellerías, de que se trate.

Siguiendo a Parejo, podría decirse que, en sentido estricto, sólo son reglamentos los dictados por los gobiernos de la nación o autonómicos, si bien existen otras disposiciones generales desde administraciones independientes, autónomas, locales, etc. que este autor califica de "normas estatutarias" (Parejo, ${ }^{73}$. En todo caso, aquí se considera a todos ellos reglamentos ${ }^{74}$, sin perjuicio de que hay que estar a la naturaleza concreta de cada norma de que se trate para determinar las posibilidades de desplegar efectos jurídicos.

\subsection{La potestad reglamentaria atribuida a diversos entes por su autonomía o independencia constitucional}

La Constitución reconoce la garantía institucional de la autonomía a los entes territoriales (art. 137 $\mathrm{CE}^{75}$ ) así como a Administraciones corporativas como las universidades (art. 27. $10^{\circ} \mathrm{CE}^{76}$ ). Este reconocimiento constitucional de autonomía sirve para fundamentar la atribución legal de potestad reglamentaria a estas administraciones y fortalece las posibilidades de su extensión.

Así, en virtud de la Ley 7/1985 reguladora de las Bases de Régimen Local (LBRL), los Plenos de Ios Municipios y Diputaciones pueden dictar "Ordenanzas" y "Presupuestos" (también "Reglamentos orgánicos" los municipios ${ }^{77}$ ). Estas normas son un particular tipo de disposiciones generales, en rigor no identificables con los reglamentos, puesto que no son desarrollo o ejecución de textos legales, sino traducción de opciones locales que han de someterse a los límites externos de las leyes. No obstante, y como se ha dicho, aquí se maneja un concepto más amplio y flexible de reglamento que incluye como tales a estas normas locales.

71 Artículo 153. "El control de la actividad de los órganos de las Comunidades Autónomas se ejercerá: [...] c) Por la jurisdicción contenciosoadministrativa, el de la administración autónoma y sus normas reglamentarias."

72 En Navarra hay Decretos "forales", si bien por lo general se denominan "Decretos" con procedencia de la denominación particular que dicho gobierno tenga, como "Consejo de Gobierno", "Consell", "Xunta" o "Junta".

73 Afirma que prefiere llamarlas normas estatutarias con alusión a que son fruto de un estatuto específico en el seno del Estado. PAREJO ALFONSO, Luciano y otros, Manual de Derecho administrativo, cit. págs. 263 y ss.

74 Personalmente creo que esta terminología nos conduce al ordenamiento privatístico de asociaciones, organizaciones, empresas, etc.

75 Artículo 137: “El Estado se organiza territorialmente en municipios, en provincias y en las Comunidades Autónomas que se constituyan. Todas estas entidades gozan de autonomía para la gestión de sus respectivos intereses."

76 "Se reconoce la autonomía de las Universidades, en los términos que la ley establezca."

77 Así, ex arts. 22. $1^{\circ}$ y 55 para Ayuntamientos, 33 para Diputaciones, LBRL. 
Al respecto, surgen cuestiones complejas sobre el respeto de las diferentes reservas de ley y la relación de estas normas locales con la ley. El Tribunal Constitucional ${ }^{78}$ señala que la reserva de ley ha de ser observada de forma flexible respecto de los municipios, si bien no en una ámbito sensible como el sancionador, sobre el que recae una reserva de ley intensa. Por otra parte, la mayoría de la doctrina considera que los "Bandos Municipales" dictados por los Alcaldes (art. 21. 1 e) LBRL) tienen una naturaleza propia y no deben ser considerados reglamentos.

Por cuanto a las universidades, "la autonomía de las Universidades comprende:[...] La elaboración de sus Estatutos [...] así como de las demás normas de régimen interno ${ }^{79}$. Así, de conformidad con el procedimiento marcado por sus estatutos, las universidades pueden aprobar normativa de alcance diverso. A veces se les otorga el nombre de "reglamento"80. A veces a estas normas se las bautiza simplemente como "normativa"81. Mientras que los Estatutos de la Universidad son aprobados por el gobierno correspondiente por medio de decreto, una vez operado un control de legalidad ${ }^{82}$ y posteriormente publicados, surgen no pocas dudas respecto de la naturaleza y alcance del resto de las normas universitarias en tanto en cuanto no son publicadas en un boletín oficial. De considerarse órdenes o instrucciones no reglamentarías, es dudosa la proyección de sus efectos a un colectivo de destinatarios tan amplio como es el propio de las universidades.

De otra parte, órganos constitucionales como el Tribunal Constitucional o el Consejo General del Poder Judicial cuentan también por ley (art. 2. 2 LOTC $^{83}$ y art. 110 LOPJ, respectivamente) de potestad reglamentaria para su funcionamiento $y$ organización, así como respecto del personal y servicios. Se trata de una potestad atribuida legalmente, que se ha fundamentado constitucionalmente por la necesaria independencia de los órganos jurisdiccionales ${ }^{84}$. En el caso del Tribunal Constitucional, se les denomina legalmente "Reglamentos" y en el caso del CGPJ "Acuerdos".

\subsection{La potestad reglamentaria de administraciones independientes y organismos públicos}

El Tribunal Constitucional también ha permitido que se atribuya potestad reglamentaria a agencias independientes. En este sentido, se ha dicho que la potestad originaria del Gobierno (art. 97 CE) permite, la posibilidad de "delegaciones singulares" de éste ${ }^{85}$. La sentencia 135/1992 (FJ $\left.3^{\circ}\right)$ permitió la posible advocación de potestad reglamentaria "a instituciones como el Banco de España, asesor de aquél [el gobierno] y ejecutor inmediato de su política monetaria y crediticia [...], que [...] tiene conferida explícitamente la potestad reglamentaria en el ámbito de su ac-

78 En sentencias como la 132/2001, de 8 de junio.

79 Artículo 2 de la Ley Orgánica de Universidades, al respecto, ver sentencia del Tribunal Constitucional 55/1989, de 23 de febrero.

80 Ejemplo,: "Reglamento electoral de la Universidad de Alicante", "reglamento de uso de la biblioteca", "reglamento de evaluación del estudiante", "reglamento de régimen interno de la Facultad de Derecho", etc.

81 Ejemplo: "Normativa sobre premios extraordinarios".

82 Así, artículo 6. $2^{\circ}$ de la Ley Orgánica de Universidades.

83 Ley Orgánica 2/1979, del Tribunal Constitucional: "Dos. El Tribunal Constitucional podrá dictar reglamentos sobre su propio funcionamiento y organización, así como sobre el régimen de su personal y servicios, dentro del ámbito de la presente Ley. Estos reglamentos, que deberán ser aprobados por el Tribunal en Pleno, se publicarán en el "Boletín Oficial del Estado", autorizados por su Presidente." 
tuación". Y en la sentencia 133/1997, de 16 de julio, se reconoce también sin problemas la potestad reglamentaria atribuida a la Comisión Nacional del Mercado de Valores. De este modo, diversas agencias independientes tienen reconocida la potestad de dictar reglamentos bajo una variada terminología: se habla de "Circulares" ${ }^{86}$ o "Instrucciones" 87 Y cabe recordar lo ya dicho: estas "Circulares" e "Instrucciones" nada tienen que ver con las generalmente conocidas circulares, órdenes e instrucciones que no son reglamentos.

Cabe señalar que las Circulares del Banco de España, por ejemplo, regulan el ámbito concreto de actuación de estas agencias. Ahora bien, ello no quiere decir que sus alcance sea únicamente ad intra, esto es, el de su organización interna, sino que, por el contrario, trascienden ad extra a todo el sector del que se ocupan con una clara eficacia externa. El Tribunal Constitucional ha justificado la dotación de potestad reglamentaria por ley con este alcance también ad extra, al considerar que se trata de ordenación del sector específico (telecomunicaciones, bancario, etc.). Por ello, a partir de la atribución legal de potestad reglamentaria se permite que estos entes puedan generar normas que obliguen a todos los implicados en la materia a la que se refieren ${ }^{88}$.

Por último, al configurar su estatuto, el Gobierno puede atribuir potestad reglamentaria a los organismos públicos para ordenar aspectos secundarios del funcionamiento del servicio encomendado, (artículo 42.2 de la Ley $6 / 1997^{89}$ ). Se trata, quizá, de la potestad reglamentaria más débil reconocida legalmente, a un escaso paso de las órdenes e instrucciones no reglamentarias que se siguieron anteriormente.

\section{Cómo SE APRUEBA UN REGLAMENTO}

Como se dijo, una nota distintiva de una reglamento respecto de un acto administrativo o de una instrucción o circular, es que quedan sujetos a un procedimiento de creación específico, así como a la publicación. En cada caso el procedimiento ha de estar regulado por la ley que configura la potestad reglamentaria concreta del Gobierno o Administración de que se trate. Dada la diversidad de reglamentos posibles, cabe tomar como ejemplo el de los reglamentos del Gobierno de la Nación. El artículo 24 de la Ley del Gobierno, detalla las siguientes fases de elaboración:

- $\quad$ Proyecto de reglamento por parte del centro directivo competente, acompañado de informe justificativo y memoria económica.

- Posibles informes previos preceptivos o a solicitud. Es obligatorio el informe sobre el impacto por razón de género; es especialmente importante y también obligatorio el informe de la Secretaría General Técnica. En ocasiones, es obligatorio el informe del Consejo de Estado o del Ministerio de Administraciones Públicas -en este caso, si se trata de

86 Banco de España, Comisión Nacional del Mercado de Valores.

87 Comisión del Mercado de las Telecomunicaciones, en virtud del Real Decreto Legislativo 6/1996, de 29 de octubre.

88 Sentencia del Tribunal Constitucional 37/1997, de 27 de febrero.

89 Ley 6/1997, de 14 de abril, de Organización y Funcionamiento de la Administración General del Estado, artículo 42 . Personalidad jurídica y potestades.

2. Dentro de su esfera de competencia, les corresponden las potestades administrativas precisas para el cumplimiento de sus fines, en los términos que prevean sus estatutos, salvo la potestad expropiatoria. Los estatutos podrán atribuir a los Organismos públicos la potestad de ordenar aspectos secundarios del funcionamiento del servicio encomendado, en el marco y con el alcance establecido por las disposiciones que fijen el régimen jurídico básico de dicho servicio. 
un tema competencial-. Si la materia es de política social y económica, es obligatorio el informe del Consejo Económico y Social ${ }^{90}$; si afecta a Administración de justicia, es preceptivo el informe del Consejo General del Poder Judicial ${ }^{91}$.

- $\quad$ Si el reglamento afecta a los derechos e intereses legítimos de ciudadanos, se les dará audiencia previa (en razón del artículo 105 a) CE) directamente o a través de las organizaciones y asociaciones reconocidas por la ley que los agrupen o los representen y cuyos fines guarden relación directa con el objeto de la disposición. También es posible el sometimiento a información pública. Estos trámites tienen diversas excepciones en la ley.

- En todos los casos, la publicación en el BOE es condición necesaria para la entrada en vigor del reglamento de que se trate.

Por cuanto a los reglamentos de los gobiernos autonómicos, se reproduce un esquema semejante en sus respectivas leyes de gobierno ${ }^{92}$. En el caso de las ordenanzas aprobadas por los entes locales, hay que seguir básicamente el artículo $49 \mathrm{LRBL}^{93}$ : se aprueba inicialmente por el Pleno de la entidad local -Ayuntamiento o Diputación- el proyecto de Ordenanza. Después, se somete la misma a información pública y se da audiencia a los interesados que pueden plantear reclamaciones y sugerencias. Si las hay, las resuelve el Pleno, al momento que aprueba, definitivamente, la Ordenanza. La publicación en el Boletín Oficial de la correspondiente provincia viene exigida por el artículo 70 LRBL.

\section{CÓMO CONTROLAR UN REGLAMENTO}

\subsection{Nulidad, invalidez e inaplicación de reglamentos}

Quienes tienen atribuida constitucional o legalmente la potestad reglamentaria han de ejercerla de conformidad a la Constitución y las Leyes (arts. $9.1^{\circ}, 97.1^{\circ}$ y $103.1^{\circ} \mathrm{CE}$, entre otros) y con sometimiento al principio de jerarquía (art. 9. $3^{\circ}$ CE) así como legalidad y reserva de ley. La Constitución ha centrado en los Tribunales ordinarios el control de la potestad reglamentaria y la legalidad de la actuación administrativa ${ }^{94}$, así como el sometimiento de ésta a los fines que la justifican (art. 106. $1^{\circ}\left(\mathrm{CE}^{95}\right)$. Frente al control de la constitucionalidad de las leyes, concentrado en el Tribunal Constitucional, el control de los reglamentos se sustancia, esencialmente, ante los tribunales ordinarios y su concreción se hace depender del diseño legalmente establecido.

90 Así, en virtud de la Ley 21/1991.

91 En razón del art. 108 Ley Orgánica del Poder Judicial.

92 Por ejemplo, artículo 49 bis de la Ley 5/1983, de 30 de diciembre, de gobierno valenciano.

93 Artículo 49: “La aprobación de las ordenanzas locales se ajustará al siguiente procedimiento:

a) Aprobación inicial por el Pleno.

b) Información pública y audiencia a los interesados por el plazo mínimo de treinta días para la presentación de reclamaciones y sugerencias. c) Resolución de todas las reclamaciones y sugerencias presentadas dentro del plazo y aprobación definitiva por el Pleno.

En el caso de que no se hubiera presentado ninguna reclamación o sugerencia, se entenderá definitivamente adoptado el acuerdo hasta entonces provisional." (Este párrafo final ha sido incorporado por la Ley 11/1999).

Debe también tenerse en cuenta el Real Decreto Legislativo 2/2004, de 5 de marzo, por el que se aprueba el texto refundido de la Ley Reguladora de las Haciendas Locales. El mismo regula en su artículo 17 la "Elaboración, publicación y publicidad de las ordenanzas fiscales".

94 Sobre el tema, recientemente y por todos, FERNÁNDEZ SALMERÓN, Manuel, El control jurisdiccional de los reglamentos : procedimiento administrativo, proceso judicial y potestad reglamentaria, Atelier, 2003. También, GARCÍA DE ENTERRÍA, Eduardo, Legislación delegada potestad reglamentaria y control judicial, Civitas, Madrid, 1998 y, muy útil, BAÑO LEÓN, José María y MOROTE SARRIÓN, José Vicente, "El control de los reglamentos ilegales", en Derecho administrativo I: Introducción y Ordenamiento Jurídico, Iustel.com, 2002. De forma particular, de interés, BLANQUER CRIADO, David, El control de los Reglamentos arbitrarios, Civitas, Madrid, 1998. 
Una particularidad respecto de los reglamentos es la posibilidad de que tienen los jueces y tribunales de no aplicarlos si los consideran contrarios al ordenamiento jurídico o al principio de jerarquía. Esta posibilidad no la tienen cuando se trata de leyes, que ante las dudas de constitucionalidad deben ser cuestionadas al Tribunal Constitucional. Así, el artículo 6 LOPJ dispone que "Ios jueces y tribunales no aplicarán los reglamentos contrarios a la Constitución, a la ley o al principio de jerarquía normativa". La fundamentación constitucional de la inaplicación judicial se busca en el artículo $117.1^{\circ}$ CE por cuanto prescribe que los jueces y Tribunales están sometidos únicamente al imperio de la Ley. De este modo, todo juez deben controlar la legalidad de un reglamento para, en su caso, no aplicarlo. Esta técnica de control difuso como recuerda Baño ${ }^{96}$ es imperfecta, por cuanto no depura el ordenamiento jurídico, sino que sólo garantiza al ciudadano que no se le aplican reglamentos ilegales. Asimismo señala que no genera seguridad, pues desde la independencia judicial, cada tribunal puede considerar aplicable o no un reglamento.

También con este autor cabe señalar que la inaplicación de los reglamentos opera especialmente en el ámbito de la jurisdicción civil y laboral. La jurisdicción contencioso-administrativa no debe declarar inaplicables los reglamentos ile- gales sino, como adelante se concreta, plantear la cuestión de ilegalidad o declararlos ilegales, si se trata de un Tribunal con competencia para ello.

\subsection{El control por la misma Administración}

Pese a que la Constitución centre el control de los reglamentos en los tribunales ordinarios, no se excluye el control jurídico administrativo de los reglamentos. El artículo 107. 3 de la Ley 30/ 1992 excluye que alguien pueda recurrir directamente un reglamento ante la vía administrativa ${ }^{97}$. Sin perjuicio de lo anterior, este mismo artículo prescribe la posibilidad de que alguien recurra ante la Administración el reglamento de forma indirecta: se recurre el acto administrativo concreto que aplica el reglamento en cuestión, sobre la base de que el reglamento es contrario al ordenamiento jurídico y, por ello, el acto administrativo impugnado. La Administración que resuelve -el mismo órgano que dictó el reglamento cuestionado- puede en su caso anular el acto administrativo recurrido, pero no puede anula el reglamento impugnado sólo indirectamente. En tal supuesto, procedería una revisión de oficio para declarar la nulidad del reglamento.

Por cuanto a la revisión de oficio de reglamentos ilegales, cabe señalar que es posible desde la

95 “1. Los Tribunales controlan la potestad reglamentaria y la legalidad de la actuación administrativa, así como el sometimiento de ésta a los fines que la justifican."

96 En concreto en BAÑO LEÓN, José María y MOROTE SARRIÓN, José Vicente, "El control de los reglamentos ilegales", cit.

97 “3. Contra las disposiciones administrativas de carácter general no cabrá recurso en vía administrativa.

Los recursos contra un acto administrativo que se funden únicamente en la nulidad de alguna disposición administrativa de carácter general podrán interponerse directamente ante el órgano que dictó dicha disposición." 
reforma de 1999 (art. 102 Ley 30/1992 ${ }^{98}$ ). La consecuencia de la revisión de oficio es diferente de la simple derogación: esta última no tiene efecto retroactivo, mientras que la revisión deja sin efectos ex tunc. Es posible que un interesado inste una revisión de oficio y que la Administración considere oportuno abrir el procedimiento, es decir, quien insta no tiene derecho a que se abra tan siquiera el procedimiento de la revisión de oficio. En todo caso, no hay que olvidar que cualquier interesado cuenta siempre con el posible recurso directo contra el reglamento en el ámbito jurisdiccional, que ahora se aborda.

\subsection{El control por la jurisdicción ordinaria: recurso directo, indirecto y cuestión de legalidad}

En la actualidad, rige el diseño de recursos establecido por la Ley 29/1998 (LJCA). En su virtud, cualquier persona puede impugnar directamente las "disposiciones de carácter general" (Art. $25^{99}$ ) hasta los dos meses después de su publi- cación y lograr una declaración de nulidad de pleno Derecho total o parcial. Ahora bien, para el caso de reconocerse la nulidad, los tribunales "no podrán determinar la forma en que han de quedar redactados los preceptos de una disposición general en sustitución de los que anularen" (Art. 71. $2^{\circ}$ LJCA). También cabe señalar los que “Las sentencias firmes que anulen un precepto de una disposición general no afectarán por sí mismas a la eficacia de las sentencias o actos administrativos firmes que lo hayan aplicado antes de que la anulación alcanzara efectos generales, salvo en el caso de que la anulación del precepto supusiera la exclusión o la reducción de las sanciones aún no ejecutadas completamente" (Art. 73 LJCA). Cabe añadir que es posible que un recurso directo se sustancie a través del procedimiento especial de protección de derechos fundamentales (Art. 114-122 LJCA).

Además del recurso directo, cualquier persona puede, al impugnar un acto administrativo, fundar su recurso entre otros motivos en la ilegalidad -o inconstitucionalidad- de un reglamento.

98 Artículo 102. Revisión de disposiciones y actos nulos (modificado por Ley 4/1999): “1. Las Administraciones Públicas, en cualquier momento, por iniciativa propia o a solicitud de interesado, y previo dictamen favorable del Consejo de Estado u órgano consultivo equivalente de la Comunidad Autónoma, si lo hubiere, declararán de oficio la nulidad de los actos administrativos que hayan puesto fin a la vía administrativa o que no hayan sido recurridos en plazo, en los supuestos previstos en el artículo 62.1.

2. Asimismo, en cualquier momento, las Administraciones públicas de oficio, y previo dictamen favorable del Consejo de Estado u órgano consultivo equivalente de la Comunidad Autónoma si lo hubiere, podrán declarar la nulidad de las disposiciones administrativas en los supuestos previstos en el artículo 62.2.

3. El órgano competente para la revisión de oficio podrá acordar motivadamente la inadmisión a trámite de las solicitudes formuladas por los interesados, sin necesidad de recabar dictamen del Consejo de Estado u órgano consultivo de la Comunidad Autónoma, cuando las mismas no se basen en alguna de las causas de nulidad del artículo 62 o carezcan manifiestamente de fundamento, así como en el supuesto de que se hubieran desestimado en cuanto al fondo otras solicitudes sustancialmente iguales.

4. Las Administraciones Públicas al declarar la nulidad de una disposición o acto, podrán establecer, en la misma resolución, las indemnizaciones que proceda reconocer a los interesados, si se dan las circunstancias previstas en los artículos 139.2 y 141.1 de esta Ley; sin perjuicio de que, tratándose de una disposición, subsistan los actos firmes dictados en aplicación de la misma.

5. Cuando el procedimiento se hubiera iniciado de oficio, el transcurso del plazo de tres meses desde su inicio sin dictarse resolución producirá la caducidad del mismo. Si el procedimiento se hubiera iniciado a solicitud de interesado, se podrá entender la misma desestimada por silencio administrativo."

99 Artículo 25: "1. El recurso contencioso-administrativo es admisible en relación con las disposiciones de carácter general y con los actos expresos y presuntos de la Administración Pública que pongan fin a la vía administrativa, ya sean definitivos o de trámite, si estos últimos deciden directa o indirectamente el fondo del asunto, determinan la imposibilidad de continuar el procedimiento, producen indefensión o perjuicio irreparable a derechos o intereses legítimos.

2. También es admisible el recurso contra la inactividad de la Administración y contra sus actuaciones materiales que constituyan vía de hecho, en los términos establecidos en esta Ley." 
Es el llamado recurso indirecto (Art. 26 LJCA $^{100}$ ). Para el mismo, no es necesario haber impugnado directamente el reglamento en cuestión en el referido plazo de dos meses, sino que el plazo que habrá de seguirse es el marcado por el acto administrativo, que es lo que se recurre directamente. Asimismo, la competencia del tribunal ante el que se ha de recurrir la determina el acto administrativo, no el reglamento impugnado indirectamente.

Ante un recurso indirecto, el tribunal competente puede considerar la ilegalidad -o inconstitucionalidad- del reglamento impugnado. Si es así, pueden suceder dos cosas: que ese tribunal sea también el competente para declarar la ilegalidad del acto. En este caso, su sentencia puede declarar a la vez la nulidad del acto y la del reglamento, con los mismos efectos antes vistos. Por el contrario, es bien posible que el tribunal que sí era competente para la revisión del acto administrativo y que lo declaró nulo porque consideró ilegal el reglamento, no sea el tribunal competente para declarar la ilegalidad del reglamento. En este supuesto, entra en juego la llamada "cuestión de legalidad" (Art. 27101, 123-126 $\left.\mathrm{LJCA}^{102}\right)$. El juez que ha declarado la nulidad del acto, debe plantear una pregunta de legalidad al tribunal que sí que es competente para declarar la misma. Dicha cuestión de legalidad será relativa a los preceptos del reglamento que hayan servido para declarar la nulidad del acto administrativo. Cabe señalar que "la sentencia que resuelva la cuestión de ilegalidad no afectará a la situación jurídica concreta derivada de la sentencia dictada por el Juez o Tribunal que planteó aquélla" (Art. 126, 5 LJCA). Es decir, el acto administrativo inicialmente impugnado ya no es objeto de la cuestión de legalidad, si bien, respecto del reglamento ilegal, la sentencia que resuelve la cuestión de legalidad tendrá los efectos señalados anteriormente.

\subsection{El control por el Tribunal Constitucional}

Como se dijo, el artículo 106 CE centra el control de los reglamentos en los tribunales ordinarios. De otra parte, los artículos $161.1^{\circ}$ a) y $163 \mathrm{CE}$, así como el artículo 27 LOTC excluyen el control directo de los reglamentos por el Tribunal Constitucional (al menos los del Estado ${ }^{103}$ ). Ahora bien, ello no obsta la posibilidad de que el alto tribunal controle la constitucionalidad (Caamaño, 1994) -nunca la legalidad- de un reglamento por diversas vías.

- En un recurso de amparo se enjuicia si el acto del poder público -que bien puede ser un reglamento- es o no inconstitucional (Sentencia 9 de 1995, 16 de enero, FJ $2^{\circ}$ ). Se trata, pues, de un control indirecto, vincula-

100 Artículo 26: "1. Además de la impugnación directa de las disposiciones de carácter general, también es admisible la de los actos que se produzcan en aplicación de las mismas, fundada en que tales disposiciones no son conformes a Derecho.

2. La falta de impugnación directa de una disposición general o la desestimación del recurso que frente a ella se hubiera interpuesto no impiden la impugnación de los actos de aplicación con fundamento en lo dispuesto en el apartado anterior."

101 Artículo 27: “1. Cuando un Juez o Tribunal de lo Contencioso-administrativo hubiere dictado sentencia firme estimatoria por considerar ilegal el contenido de la disposición general aplicada, deberá plantear la cuestión de ilegalidad ante el Tribunal competente para conocer del recurso directo contra la disposición, salvo lo dispuesto en los dos apartados siguientes.

2. Cuando el Juez o Tribunal competente para conocer de un recurso contra un acto fundado en la invalidez de una disposición general lo fuere también para conocer del recurso directo contra ésta, la sentencia declarará la validez o nulidad de la disposición general.

3. Sin necesidad de plantear cuestión de ilegalidad, el Tribunal Supremo anulará cualquier disposición general cuando, en cualquier grado, conozca de un recurso contra un acto fundado en la ilegalidad de aquella norma."

102 En resumen: en virtud del artículo 123, el Juez o Tribunal planteará, mediante auto, la cuestión de ilegalidad, cinéndose a los preceptos reglamentarios cuestionados en la demanda. En razón del artículo 126, la sentencia estimará o desestimará parcial o totalmente la cuestión y se comunicará al Juez o Tribunal que la planteó.

103 “Dos. Son susceptibles de declaración de inconstitucionalidad: [...] e) Las Leyes, actos y disposiciones normativas con fuerza de Ley de las Comunidades Autónomas, con la misma salvedad formulada en el apartado b) respecto a los casos de delegación legislativa." 
do a la protección subjetiva concreta del recurso de amparo.

- $\quad$ En el caso de conflicto de competencias (Art. 161,1 c) CE), para el caso de que se considere que un reglamento estatal o autonómico vulnera el bloque de constitucionalidad. En su caso, la sentencia podrá acordar la anulación de la disposición que originó el conflicto, que bien puede ser un reglamento ${ }^{104}$.

- Asimismo, no hay que obviar que entre las "disposiciones y resoluciones" de las comunidades Autónomas que el Gobierno de la Nación puede impugnar por considerar contrarias a la Constitución (art. 161. $2^{\circ} \mathrm{CE}$ ), pueden perfectamente encontrarse reglamentos. Éstos podrían ser, en su caso, declarados inconstitucionales por el Tribunal Constitucional.

De otra parte, y para concluir, Caamaño (1994) señala a la vista de los artículos 27. 20, 39. $1^{\circ}$ y 40. $1^{\circ}$ de la LOTC, la declaración de la inconstitucionalidad de una ley no afecta a los reglamentos que directamente la desarrollen o ejecuten. En estos casos, resultará precisa la posterior declaración de nulidad de los mismos. Así, si la ley de extranjería se declarase inconstitucional por el Tribunal Constitucional, no se consideraría nulo automáticamente el reglamento de la ley, sino que, por ejemplo habría de seguirse la vía de la revisión del artículo 102 de la Ley 30/ 1992.

\section{BIBLIOGRAFÍA}

Balaguer C., F. (1992). Fuentes del Derecho. II. Ordenamiento general del Estado y ordenamientos autonómicos. Madrid: Editorial Tecnos.
Baño L., J. (1991). Los límites constitucionales de la potestad reglamentaria. Madrid: Civitas.

Caamaño, F. (1994). El control constitucionalidad de las disposiciones reglamentarias: Madrid: Centro de Estudios Constitucionales.

De Otto, I. (1987). Derecho constitucional. Sistema de fuentes. Madrid: Ariel.

García, E. \& Férnandez R., T. (2002). Curso de Derecho Administrativo (11 a ed., vol. I.) Madrid: Civitas.

García M., Ricardo, Reserva de ley y potestad reglamentaria, Ariel, Barcelona, 1987.

Garrido F., F. (2002). Parte General. Tratado de Derecho administrativo (13 a ed., Vol. I). Tecnos.

López B., M. (1994). Naturaleza y presupuestos constitucionales de las relaciones especiales de sujeción. Madrid: Civitas.

Montilla, J. M. (2002). Los reglamentos gubernamentales. Derecho constitucional I. lustel.com.

Parada V., J. R. (2004). Parte general. Derecho administrativo (15 a ed., vol. I). Marcial Pons.

Parejo, A., L. et al. Manual de Derecho administrativo ( $5^{\mathrm{a}}$ edición). Barcelona: Ariel.

Santamaría, J. A. (2000). Principios de Derecho Administrativo (4a ed., vol. 1). Madrid: Centro de Estudios Ramón Areces.

Sentencia 108/1986, de 29 de julio, FJ 23․

Tribunal Supremo. Sentencias de 18 de enero y 7 de abril de 1997.

104 Incluso el Tribunal Constitucional ha llegado a admitir recursos competenciales frente a instrucciones y circulares, sentencia 249/1988 de 20 de diciembre. 